\title{
NILAI EKONOMI ANAK, MOTIVASI, DAN SELF-ESTEEM PEKERJA ANAK
}

\author{
Robi Rizkianto $^{1^{*}}$, Istiqlaliyah Muflikhati ${ }^{1}$, Neti Hernawati ${ }^{1}$ \\ ${ }^{1}$ Departemen IImu Keluarga dan Konsumen, Fakultas Ekologi Manusia, Institut Pertanian Bogor, \\ Bogor 16680, Indonesia \\ *)E-mail: robi_rizkianto@yahoo.com
}

\begin{abstract}
Abstrak
Analisis pengaruh nilai ekonomi dan motivasi terhadap self-esteem pekerja anak di salah satu sentra bisnis di Kabupaten Bogor merupakan tujuan dari penelitian ini. Penelitian ini melibatkan 40 pekerja anak dan orang tuanya yang dipilih dengan cara snowball. Data dianalisis menggunakan uji beda t dan uji regresi linear berganda. Hasil penelitian menunjukkan bahwa persepsi orang tua pekerja anak terkait nilai ekonomi anak masa depan dan nilai ekonomi anak saat ini berada pada kategori sedang. Motivasi (intrinsik dan ekstrinsik) dan self-esteem pekerja anak berada pada kategori sedang. Motivasi dan juga self-esteem pekerja anak laki-laki lebih tinggi dibandingkan pekerja anak perempuan. Self-esteem pekerja anak meningkat dengan bertambahnya lama anak untuk mengikuti pendidikan formal dan menurun pada anak yang putus sekolah. Self-esteem pekerja anak ini juga menurun dengan berkurangnya motivasi ekstrinsik.
\end{abstract}

Kata kunci: motivasi ekstrinsik, motivasi instrinsik, nilai ekonomi anak, pekerja anak, self-esteem

\section{Child's Economic Value, Motivation, and Self-Esteem of Child Labors}

\begin{abstract}
Analysis of influence of the child's economic value and motivation on self-esteem of child labor in one of the business center in Bogor District was the goal of this research. The study involved 40 child laborers and their parents that were selected by snowball. Data were analyzed using independent samples t-test and multiple linear regression test. The results showed that parents' perceptions of child labor related future of child's economic value and the child's economic value currently in the moderate category. Motivation of child labors (intrinsic and extrinsic) and self-esteem were also in the moderate category. Self-esteem of child labor increased by increasing length of child to attend formal education and decreased in children who was dropping outs of school. Selfesteem of child labor was also decreased with decreasing extrinsic motivation.
\end{abstract}

Keywords: child labor, economic values of child, extrinsic motivation, intrinsic motivation, self-esteem

\section{PENDAHULUAN}

Salah satu masalah pada anak yang menjadi sorotan di Indonesia adalah masalah pekerja anak. Penelitian tentang pekerja anak telah banyak dilakukan terutama di mancanegara. Salah satu contohnya adalah Meerza (2010) yang meneliti penyebab munculnya pekerja anak di Bangladesh. Hasil penelitian menemukan bahwa pekerja anak muncul karena membantu anggota keluarga bekerja. International Labour Organization (ILO) dan Badan Pusat Statistik (BPS) juga pernah melakukan survei di Indonesia pada tahun 2009 tentang karakteristik dan jumlah pekerja anak. Hasil survei menunjukkan bahwa jumlah keseluruhan anak berusia 5-17 tahun yang bekerja sekitar 58,8 juta. Berdasarkan jumlah tersebut, 48,1 juta $(81,8 \%)$ anak bersekolah, 24,3 juta $(41,2 \%)$ anak terlibat dalam pekerjaan rumah, dan 6,7 juta $(11,4 \%)$ tergolong sebagai idle yaitu tidak bersekolah, tidak membantu di rumah, dan juga tidak bekerja. Dengan demikian, fenomena pekerja anak ini menarik untuk dikaji.

Seorang anak seharusnya berada dalam lingkungan yang kondusif dan memperoleh hak untuk menempuh pendidikan yang layak. Namun, ILO (2004) menyatakan meskipun melalui pendidikan mampu meningkatkan pendapatan di masa depan tapi tidak dapat dipungkiri bahwa hal tersebut bukan yang mudah bagi keluarga untuk membandingkan antara nilai keuntungannya dengan biaya sekolah yang harus dibayarkan. Sehingga muncul kondisi antar pekerja anak memiliki motif yang berbeda ketika harus memutuskan menjadi pekerja anak.

Motivasi anak terjun ke dunia kerja dipengaruhi oleh faktor internal dan eksternal. 
Faktor internal adalah segala sesuatu yang terdapat dalam diri, sedangkan faktor eksternal merupakan hal-hal di luar yang menarik anak untuk bekerja. Keputusan seorang anak untuk bekerja terkait erat dengan status ekonomi keluarga (Usman \& Nachrowi, 2004). ILO (2004) menambahkan bahwa keputusan anakanak untuk bekerja disebabkan karena adanya tuntutan ekonomi dan keluarga telah mengenalkan berbagai nilai peraturan keluarga dan tanggung jawab. Keikutsertaan anak untuk menjadi pekerja juga berkaitan dengan nilai anak dalam pandangan orang tua, seperti orang tua yang memandang anak sebagai nilai tukar (harga) dan nilai guna (utilitas) dalam keluarga.

Selain motivasi, hal yang penting untuk ditelaah adalah dampak dari keikutsertaan anak dalam bekerja pada dirinya sendiri mengingat pada masa ini, anak harus mendapat pendidikan yang layak. Menurut ILO (2004), anak yang telah memutuskan untuk terjun ke dunia kerja akan memiliki motivasi yang rendah untuk melanjutkan sekolah. Anak yang ikut bekerja memiliki peluang yang besar untuk juga berdampak pada kegagalan dan belajar dalam waktu yang sama juga akan berdampak pada prestasi yang rendah. Smeru Research Institute (2002) juga melakukan penelitian di Indonesia yang menunjukkan bahwa kegagalan anak menempuh pendidikan anak akibat dari faktor kemiskinan keluarga dan anak yang turut membantu orang tua bekerja.

Lingkungan adalah tempat anak berada akan memengaruhi kondisi self-esteem anak (Calhoun \& Acocella, 1990). Anak-anak yang bekerja akan mendapatkan stereotip negatif dari lingkungannya. Namun di sisi lain, adanya teman-teman sebaya dan sepemahaman dengan pekerja anak justru bisa meningkatkan self-esteem pekerja anak. Berdasarkan pemaparan tersebut, penelitian ini bertujuan untuk menganalisis menganalisis nilai ekonomi pekerja anak, motivasi pekerja anak, pengambilan keputusan orang tua pekerja anak, dan self-esteem pekerja anak. Penelitian ini juga bertujuan untuk menganalisis perbedaan antara nilai ekonomi anak, motivasi, dan self-esteem antara pekerja anak lak-laki dan perempuan. Selain itu, penelitian ini juga dilakukan untuk menganalisis pengaruh nilai ekonomi dan motivasi terhadap self-esteem pekerja anak.

\section{METODE}

Penelitian menggunakan desain cross sectional dan memilih lokasi penelitian di salah satu sentra industri sepatu di Kota Bogor. Kegiatan pengumpulan data dilaksanakan pada bulan April-Mei 2011. Penelitian ini dilakukan dengan wawancara pada 40 orang pekerja anak yang berusia 12-17 tahun dan orang tuanya.

Data yang dikumpulkan adalah data primer yaitu karakteristik anak, karakteristik keluarga, nilai ekonomi, motivasi, dan self-esteem. Karakteristik anak terdiri atas usia, jenis kelamin, lama pendidikan, lama bekerja, dan upah kerja. Karakteristik keluarga terdiri atas usia orang tua, pendidikan orang tua, pekerjaan orang tua, besar keluarga, dan pendapatan keluarga.

Nilai ekonomi anak yang diukur adalah penilaian orang tua terhadap anak dari segi ekonomi dalam keluarga. Kuesioner yang digunakan dikembangkan dari Kartino (2005) yang dimodifikasi berdasarkan teori dari Bryant (1990) mengenai investasi anak. Kuesioner terdiri atas 14 pernyataan. Selanjutnya, kuesioner motivasi pekerja anak dibuat berdasarkan teori motivasi (Santrock, 2007). Motivasi dibagi menjadi dua jenis yakni motivasi intrinsik (20 pernyataan) dan motivasi ekstrinsik (23 pernyataan). Kuesioner self-esteem menggunakan kuesioner yang disusun oleh Harril (2008). Self-esteem terdiri atas perasaan (16 pernyataan), keyakinan (12 pernyataan), dan perilaku (17 pernyataan).

Kuesioner nilai ekonomi, motivasi, dan self-esteem yang disusun menggunakan skala jawaban Likert yaitu sangat tidak setuju, tidak setuju, setuju, dan sangat setuju. Pada pernyataan positif, skor 1 diberikan untuk jawaban sangat tidak setuju, skor 2 diberikan untuk jawaban tidak setuju, skor 3 diberikan untuk jawaban setuju, dan skor 4 diberikan untuk jawaban sangat setuju. Sebaliknya pada pernyataan negatif, skor 1 diberikan untuk jawaban sangat setuju, skor 2 diberikan untuk jawaban setuju, skor 3 diberikan untuk jawaban tidak setuju, dan skor 4 diberikan untuk jawaban sangat tidak setuju. Skor yang diperoleh dijumlahkan dan distandardisasi menjadi bentuk indeks. Selanjutnya, indeks dikategorikan berdasarkan interval kelas, yaitu rendah $(<33,3)$, sedang $(33,3-66,7)$, dan tinggi $(>66,7)$.

Data yang telah dikumpulkan dianalisis menggunakan analisis deskriptif dan inferensial. Analisis data menggunakan uji beda $t$ dan uji regresi linear berganda. Uji beda $t$ digunakan untuk menganalisis perbedaan antara nilai ekonomi anak, motivasi anak, dan 
self-esteem pekerja anak laki-laki dan perempuan. Uji regresi linear berganda dilakukan untuk menganalisis pengaruh nilai anak dan motivasi anak terhadap self-esteem pekerja anak.

\section{HASIL}

\section{Karakteristik Pekerja Anak}

Pekerja anak terdiri atas laki-laki (55\%) dan perempuan (45\%). Berdasarkan usia, anak termasuk dalam kelompok remaja pertengahan. Tiga dari empat anak yang menjadi pekerja anak masih bersekolah. Rata-rata pekerja anak masih menempuh pendidikan di tingkat Sekolah Menengah Pertama/sederajat. Selain itu, pekerja anak juga ada yang putus sekolah. Jumlah pekerja anak laki-laki $(36,3 \%)$ yang putus sekolah lebih banyak dibandingkan dengan jumlah pekerja anak perempuan $(5,5 \%)$ yang putus sekolah. Rata-rata anak telah bekerja selama 2,3 tahun. Untuk anak yang bersekolah, rata-rata waktu yang dihabiskan untuk bekerja adalah 14,5 jam per minggu. Sementara itu, untuk anak yang putus sekolah, rata-rata menghabiskan waktu untuk bekerja selama 62,56 jam per minggu. Hasil penelitian tidak menemukan banyaknya perbedaan yang signifikan pada variabel karakteristik pekerja anak antara laki-laki dan perempuan. Nilai ratarata, standar deviasi, dan koefisien uji beda karakteristik pekerja anak berdasarkan jenis kelamin disajikan pada Tabel 1. Hasil penelitian juga menunjukkan bahwa hampir setengah dari pekerja anak laki-laki $(45,4 \%)$ lebih suka untuk bersekolah. Namun, lebih dari separuh pekerja anak perempuan lebih suka untuk bersekolah dan bekerja $(55,6 \%)$.

Tabel 1 Nilai rata-rata, standar deviasi, dan koefisien uji beda karakteristik pekerja anak berdasarkan jenis kelamin

\begin{tabular}{|c|c|c|c|c|}
\hline \multirow{2}{*}{ Karakteristik } & \multicolumn{3}{|c|}{ Rata-rata \pm Standar deviasi } & \multirow{2}{*}{$p$-value } \\
\hline & $L$ & $\mathrm{P}$ & Total & \\
\hline $\begin{array}{l}\text { Lama } \\
\text { pendidikan } \\
\text { (tahun) }\end{array}$ & $6,9 \pm 2,0$ & $7,7 \pm 1,7$ & $7,2 \pm 1,9$ & 0,240 \\
\hline $\begin{array}{l}\text { Lama bekerja } \\
\text { (tahun) }\end{array}$ & $2,3 \pm 1,7$ & $2,6 \pm 2,0$ & $2,3 \pm 1,9$ & 0,410 \\
\hline $\begin{array}{l}\text { Jam kerja } \\
\text { anak } \\
\text { bersekolah } \\
\text { (jam/minggu) }\end{array}$ & $14,3 \pm 7,6$ & $14,5 \pm 7,4$ & $14,5 \pm 7,4$ & 0,995 \\
\hline $\begin{array}{l}\text { Jam kerja } \\
\text { anak putus } \\
\text { sekolah } \\
\text { (jam/minggu) }\end{array}$ & $62,9 \pm 14,06$ & $60,0 \pm 0,0$ & $62,5 \pm 13,1$ & 0,853 \\
\hline
\end{tabular}

Upah membuat sepatu dapat diperoleh dari orang tua sendiri, pekerja sepatu, dan pemilik bengkel sepatu. Pekerja anak yang bersekolah secara umum upahnya diperoleh dari orang tua sendiri. Namun, pekerja anak yang telah putus sekolah lebih banyak mendapat upah dari pekerja sepatu dan pemiliki bengkel sepatu tersebut. Oleh karena itu, pengkategorian upah antara pekerja anak yang bersekolah dan putus sekolah juga dipisah agar lebih bisa membandingkan besar upah yang diperoleh anak. Hasil penelitian menunjukkan bahwa pekerja anak laki-laki yang bersekolah $(64,3 \%)$ dan perempuan $(70,4 \%)$ memperoleh upah kerja kurang dari Rp100.000,00/bulan. Hasil uji beda menunjukkan tidak terdapat perbedaan yang signifikan $(p>0,05)$ antara upah kerja pekerja anak laki-laki dan perempuan yang masih bersekolah. Rata-rata upah pekerja anak lakilaki lebih tinggi (Rp102.621 2 Rp73.343) dibandingkan dengan anak perempuan (Rp99.741士 Rp70.774)

Sementara itu, pada kelompok pekerja anak yang telah putus sekolah membuat sepatu memiliki upah yang lebih besar dibandingkan pekerja anak yang masih bersekolah. Hasil penelitian menunjukkan bahwa pekerja anak laki-laki $(75,0 \%)$ mendapat upah lebih dari Rp500.000, sedangkan pekerja perempuan $(100,0 \%)$ mendapat upah kurang dari Rp100.000. Hasil uji T-test menunjukkan tidak terdapat perbedaan yang signifikan $(p>0,05)$ pada upah kerja pekerja anak laki-laki dan perempuan yang putus sekolah.

Anak-anak yang bekerja memiliki alasan yang beragam yakni inisiatif sendiri, diminta orang tua, dan diajak teman. Sebagian besar pekerja anak laki-laki maupun perempuan memiliki alasan bekerja karena inisiatif sendiri $(L=81,8 \% ; P=88,9 \%)$. Pekerja anak umumnya bekerja karena ingin membantu orang tua. Selain itu agar dapat menghasilkan uang sendiri untuk membeli kebutuhan pribadi.

\section{Karakteristik Keluarga}

Rata-rata jumlah anggota keluarga adalah lima orang. Usia ayah termasuk usia dewasa tengah dengan rata-rata berusia 46,0 tahun, sedangkan usia ibu termasuk usia dewasa awal dengan rata-rata berusia 40,9 tahun. Rata-rata lama pendidikan ayah pekerja anak adalah lebih rendah sekitar dua tahun daripada ibu pekerja anak. Rata-rata pendapatan keluarga adalah Rp2.228.000,0/ bulan dan rata-rata pendapatan per kapita Rp431.403,4/bulan. BPS (2010) menetapkan garis kemiskinan desa dan 

kota di Jawa Barat adalah Rp201.135,00/ kapita/bulan. Hasil penelitian menunjukkan bahwa 87,5 persen pekerja anak di lokasi penelitian memiliki pendapatan keluarga lebih besar atau sama dengan garis kemiskinan dengan rata-rata sebesar Rp431.403,4/ kapita/bulan.

\section{Kontribusi Ekonomi Pekerja Anak}

Perbandingan pendapatan per kapita keluarga yang dihitung bersama upah pekerja anak dan pendapatan per kapita yang dihitung tanpa upah pekerja anak. Hal ini bertujuan untuk mengetahui besarnya kontribusi ekonomi anak terhadap pendapatan keluarga. Pendapatan keluarga yang dihitung bersama upah pekerja anak menunjukkan bahwa sebanyak 87,5 persen keluarga pekerja anak di lokasi penelitian memiliki pendapatan per kapita perbulan di atas garis kemiskinan.

Rata-rata pendapatan per kapita pekerja anak sebesar Rp431.403,4 per bulan. Namun setelah pendapatan keluarga dihitung tanpa upah pekerja anak menunjukkan bahwa 85 persen keluarga pekerja anak memiliki pendapatan per kapita per bulan di atas garis kemiskinan. Rata-rata pendapatan per kapita pekerja anak sebesar Rp396.186,1 per bulan. Artinya semakin tinggi pendapatan keluarga maka semakin kecil kontribusi pendapatan dari pekerja anak.

\section{Nilai Ekonomi}

Nilai ekonomi anak adalah keuntungan materi yang diberikan oleh anak dalam keluarga. Hal yang paling tampak pada nilai ekonomi anak adalah anak turut membantu orang tua untuk memberikan keamanan ekonomi keluarga (Kogitcibasi, 2007). Nilai ekonomi anak dilihat dari nilai ekonomi anak masa depan dan nilai ekonomi anak sekarang.

Nilai ekonomi anak masa depan. Orang tua memiliki persepsi nilai ekonomi anak di masa depan $(97,5 \%)$ yakni membesarkan anak sama dengan berinvestasi, pendidikan anak yang tinggi akan menjadi jaminan keluarga, dan anak semakin dewasa diharapkan mampu memberikan bantuan ekonomi. Orang tua menganggap anak sebagai investasi masa depan yang dapat diambil keuntungannya di masa depan. Namun, ada sebagian orang tua $(72,5 \%)$ yang masih menganggap bahwa anak hanya akan menghabiskan uang jika harus bersekolah.
Orang tua pekerja anak laki-laki $(72,7 \%)$ maupun perempuan $(72,2 \%)$ memiliki nilai ekonomi anak masa depan pada kategori sedang. Adapun rata-rata nilai ekonomi anak masa depan pada orang tua pekerja anak lakilaki $(66,6)$ lebih besar dibandingkan dengan perempuan $(65,4)$. Adapun hasil uji T-test menunjukkan tidak terdapat perbedaan yang signifikan $(p>0,05)$ antara pekerja anak laki-laki dan perempuan pada nilai ekonomi anak masa depan.

Nilai ekonomi anak sekarang. Orang tua memiliki persepsi nilai ekonomi anak sekarang yakni anak merupakan sumber penambah pendapatan keluarga $(82,5 \%)$ dan anak saat ini sudah harus bisa membayar uang sekolahnya sendiri (62,5\%). Namun, orang tua juga tidak setuju jika daripada anak bermain dan nonton televisi lebih baik waktu anak digunakan membantu pekerjaan orang tua (85\%). Hasil penelitian menunjukkan bahwa baik pekerja anak laki-laki $(77,2 \%)$ maupun perempuan $(88,8 \%)$ memiliki nilai ekonomi dalam kategori sedang. Adapun rata-rata nilai ekonomi anak sekarang, orang tua pekerja anak laki-laki $(63,8)$ lebih tinggi dibandingkan dengan perempuan (55,7). Orang tua lebih menekankan anak laki-laki untuk bekerja membuat sepatu dibandingkan perempuan. Sikap orang tua tersebut disebabkan pembuatan sepatu membutuhkan tenaga yang cukup besar. Anak perempuan dilibatkan dalam pembuatan sepatu, maka anak perempuan umumnya hanya mendapatkan tugas dalam packaging (pengemasan sepatu) dan pembuatan pola. Adapun anak laki-laki mendapatkan tugas dari awal hingga akhir yakni pembuatan pola, menjahit, pengeleman, hingga penyatuan semua pola. Oleh karena itu, hasil uji beda T-test menunjukkan terdapat perbedaan yang signifikan $(p<0,05)$ antara pekerja anak laki-laki dan perempuan pada nilai ekonomi anak sekarang.

Alasan orang tua mengizinkan anak bekerja. Orang tua memiliki peran yang besar dalam mengontrol dan mengarahkan seluruh kegiatan anak-anaknya. Orang tua pekerja anak secara keseluruhan mengetahui dan mengizinkan bahwa anaknya bekerja membuat sepatu. Hal ini disebabkan anak-anak mayoritas bekerja membuat sepatu di rumah bersama orang tuanya. Lebih dari separuh orang tua mengizinkan anaknya bekerja dengan alasan bahwa waktu anak lebih baik digunakan untuk bekerja daripada bermain. Alasan lain orang tua mengizinkan anaknya bekerja adalah anak membantu ekonomi keluarga, pekerjaan cepat selesai, memiliki 

keterampilan, dan anak merasakan susahnya mencari uang. Khusus pekerja anak perempuan, hampir seperempat orang tua pekerja anak $(38,8 \%)$ mengizinkan anaknya bekerja untuk membantu pekerjaan orang tua membuat sepatu agar pekerjaannya cepat selesai.

Keputusan orang tua dengan melibatkan dan mengizinkan anak bekerja membuat sepatu merupakan sebuah keputusan yang bisa dilihat dari sisi orang tua dan sisi anak remaja. Orang tua melihat kondisi keluarga sedang mendapatkan tekanan ekonomi. Pekerjaan orang tua yang didominasi sebagai pembuat sepatu dirasa penghasilannya tidak akan mencukupi kebutuhan keluarga jika hanya dilakukan oleh orang tua sendiri. Hal ini disebabkan besarnya upah yang diperoleh tergantung dari jumlah sepatu yang dihasilkan. Tekanan ekonomi tersebut dapat menjadi masalah bagi anak remajanya yang sangat memiliki banyak keinginan untuk membeli berbagai barang keinginannya. Papalia, Old, dan Feldman (2008) mengatakan bahwa pendapatan keluarga merupakan salah satu faktor yang memengaruhi hubungan antara orang tua dengan anak. Oleh kerena itu, orang tua membuat keputusan untuk melibatkan anak-anaknya untuk meningkatkan pendapatannya.

Dari sisi anak remaja, otonomi kebebasan menjadi minat remaja yang sangat penting. Salah satu bentuk dari otonomi kebebasan yang ingin diraih remaja yakni kemandirian. Ketika remaja memiliki uang sendiri maka remaja bisa membeli segala yang diinginkannya tanpa harus meminta lagi kepada orang tua. Hurlock (1980) mengatakan bahwa semua remaja cepat atau lambat akan menemukan bahwa uang adalah kunci kebebasan. Sepanjang orang tua melayani semua kebutuhan dan memberikan uang saku, orang tua dapat mengendalikan perilaku remaja. Kalau remaja dapat bekerja sendiri untuk memperoleh uang, anak dapat menikmati kebebasan dan kemandiriannya. Minat ini terutama pada bagaimana cara mendapatkan uang sebanyak mungkin, tanpa mempedulikan jenis pekerjaan yang dilakukan.

\section{Motivasi}

Motivasi adalah alasan individu bertingkah laku, berpikir, dan memiliki perasaan dengan cara yang dilakukannya yakni menekankan pada aktivasi dan arah dari tingkah lakunya. Motivasi individu untuk meraih sesuatu atau berprestasi dapat dibagi menjadi dua jenis utama, yakni motivasi intrinsik dan motivasi ekstrinsik. Motivasi intrinsik adalah keinginan dari dalam diri untuk menjadi kompeten dan melakukan sesuatu demi usaha itu sendiri, sedangkan motivasi ekstrinsik adalah keinginan mencapai sesuatu dengan tujuan untuk mendapatkan penghargaan eksternal atau untuk menghindari hukuman eksternal (Santrock, 2003).

Motivasi intrinsik. Lebih dari setengah pekerja anak (65\%) memiliki motivasi intrinsik pada kategori sedang. Rata-rata skor motivasi intrinsik pekerja anak laki-laki $(66,5 \%)$ lebih tinggi daripada pekerja anak perempuan $(58,8 \%)$. Hasil uji beda $t$ menunjukkan tidak terdapat perbedaan yang signifikan $(p>0,05)$ pada motivasi intrinsik pekerja anak laki-laki dan perempuan.

Motivasi ekstrinsik. Lebih dari setengah pekerja anak $(67,5 \%)$ memiliki motivasi ekstrinsik pada kategori sedang. Rata-rata skor motivasi ekstrinsik laki-laki $(48,4 \%)$ lebih tinggi dibandingakn perempuan $(39,4 \%)$. Adapun hasil uji beda $t$ juga menunjukkan terdapat perbedaan yang signifikan $(p<0,05)$ pada motivasi ekstrinsik pekerja anak laki-laki dan perempuan. Sebaran, nilai maksimum, nilai minimum, nilai rata-rata, standar deviasi, dan koefisien uji beda motivasi intrinsik dan ekstrinsik pekerja anak disajikan pada Tabel 2.

Tabel 2 Sebaran pekerja anak berdasarkan motivasi intrinsik dan ekstrinsik

\begin{tabular}{|c|c|c|c|}
\hline Kategori & Laki-laki & Perempuan & Total \\
\hline \multicolumn{4}{|c|}{ Motivasi instrinsik } \\
\hline Rendah & 0,00 & 0,0 & 0,0 \\
\hline Sedang & 54,5 & 77,8 & 65,0 \\
\hline Tinggi & 45,4 & 22,2 & 35,0 \\
\hline Total & 100,0 & 100,0 & 100,0 \\
\hline $\begin{array}{l}\text { Minimum- } \\
\text { maksimum }\end{array}$ & $36,6-95$ & $38,3-88,3$ & $36,6-95,0$ \\
\hline $\begin{array}{l}\text { Rata- } \\
\text { rata } \pm \text { standar } \\
\text { deviasi }\end{array}$ & $66,5 \pm 14,7$ & $58,8 \pm 13,0$ & $63,1 \pm 14,1$ \\
\hline$p$-value & & 0,083 & \\
\hline \multicolumn{4}{|c|}{ Motivasi ekstrinsik } \\
\hline Rendah & 13,6 & 50,0 & 30,0 \\
\hline Sedang & 81,8 & 50,0 & 67,5 \\
\hline Tinggi & 4,5 & 0,0 & 2,5 \\
\hline Total & 100,0 & 100,0 & 100,0 \\
\hline $\begin{array}{l}\text { Minimum- } \\
\text { maksimum }\end{array}$ & $10,1-69,5$ & $27,5-62,3$ & $10,1-69,5$ \\
\hline $\begin{array}{l}\text { Rata- } \\
\text { rata } \pm \text { standar } \\
\text { deviasi }\end{array}$ & $48,4 \pm 13,8$ & $39,4 \pm 11,8$ & $44,3 \pm 12,8$ \\
\hline$p$-value & & 0,033 & \\
\hline
\end{tabular}





\section{Self-Esteem}

Hasil penelitian menunjukkkan bahwa lebih dari setengah pekerja anak memiliki perasaan $(72,5 \%)$, keyakinan $(55,5 \%)$, dan perilaku $(57,5 \%)$ pada kategori sedang. Analisis uji beda T-test menunjukkan bahwa tidak terdapat perbedaan yang signifikan antara perasaan, keyakinan, dan perilaku pekerja anak laki-laki dan perempuan. Hasil penelitian pada Tabel 3 merupakan akumulasi dari perasaan, keyakinan, dan perilaku. Terdapat tiga perempat pekerja anak $(75 \%)$ berada pada kategori sedang. Rata-rata skor self-esteem pekerja anak laki-laki lebih tinggi dibandingkan dengan pekerja anak perempuan. Namun, hasil uji beda T-test menunjukkan tidak terdapat perbedaan yang signifikan $(p>0,05)$ pada selfesteem pekerja anak laki-laki dan perempuan.

\section{Pengaruh Karakteristik Pekerja anak dan Keluarga, Nilai Ekonomi, dan Motivasi terhadap Self-esteem}

Hasil uji regresi Tabel 4 menunjukkan bahwa sebesar 13,9 persen self-esteem pekerja anak dapat dijelaskan oleh variabelvariabel pada model dan sisanya sebesar 86,1 persen dijelaskan oleh variabel lain di luar variabel yang digunakan. Variabel yang berpengaruh secara signifikan terhadap selfesteem pekerja anak yakni status pendidikan, lama pendidikan, dan motivasi ekstrinsik pekerja anak. Variabel status pendidikan berpengaruh negatif dan signifikan terhadap self-esteem, artinya jika pekerja anak merupakan anak yang bersekolah, maka akan menurunkan self-esteem pekerja anak. Kedua, lama pendidikan sekolah berpengaruh positif dan signifikan terhadap self-esteem. Artinya semakin lama pekerja anak menempuh pendidikan maka akan semakin meningkatkan self-esteem pekerja anak. Ketiga, motivasi ekstrinsik berpengaruh negatif dan signifikan terhadap self-esteem. Artinya semakin tinggi motivasi ekstrinsik pekerja anak maka akan semakin menurunkan self-esteem pekerja anak.

Tabel 3 Sebaran pekerja anak berdasarkan kategori self-esteem

\begin{tabular}{|c|c|c|c|}
\hline Kategori & Laki-laki & Perempuan & Total \\
\hline Rendah & 0,0 & 0,0 & 0,0 \\
\hline Sedang & 68,1 & 83,3 & 75,0 \\
\hline Tinggi & 31,8 & 16,6 & 25,0 \\
\hline Total & 100,0 & 100,0 & 100,0 \\
\hline $\begin{array}{l}\text { Minimum- } \\
\text { maksimum }\end{array}$ & $45,1-77,7$ & $52,5-70,3$ & $45,1-77,7$ \\
\hline $\begin{array}{l}\text { Rata- } \\
\text { rata } \pm \text { standar } \\
\text { deviasi }\end{array}$ & $62,2 \pm 8,4$ & $60,9 \pm 5,3$ & $61,7 \pm 7,1$ \\
\hline$p$-value & & 0,557 & \\
\hline
\end{tabular}

Tabel 4 Koefisien regresi karakteristik pekerja anak, nilai ekonomi, dan motivasi terhadap self-esteem pekerja anak

\begin{tabular}{|c|c|c|c|}
\hline \multirow{2}{*}{ Variabel } & \multicolumn{3}{|c|}{ Self-esteem } \\
\hline & $\mathrm{B}$ & $\beta$ & Sig. \\
\hline $\begin{array}{l}\text { Jenis kelamin }(0= \\
\text { Perempuan; } 1=\text { Laki- } \\
\text { laki) }\end{array}$ & 4,45 & 0,228 & 0,234 \\
\hline Umur contoh (tahun) & $-2,407$ & $-0,393$ & 0,211 \\
\hline $\begin{array}{l}\text { Lama pendidikan } \\
\text { contoh (tahun) }\end{array}$ & 2,656 & 0,54 & $0,069^{*}$ \\
\hline $\begin{array}{l}\text { Status pendidikan } \\
\text { contoh } \\
\text { (0=putus sekolah, } \\
1=\text { bersekolah) }\end{array}$ & $-11,504$ & $-0,5$ & $0,068^{*}$ \\
\hline $\begin{array}{l}\text { Lama kerja contoh } \\
\text { (tahun) }\end{array}$ & 0,24 & 0,049 & 0,8 \\
\hline Umur ayah (tahun) & 0,169 & 0,134 & 0,503 \\
\hline $\begin{array}{l}\text { Pendidikan ayah } \\
\text { (tahun) }\end{array}$ & 0,04 & 0,009 & 0,963 \\
\hline Besar keluarga (orang) & 0,902 & 0,184 & 0,399 \\
\hline $\begin{array}{l}\text { Pendapatan per kapita } \\
\text { (Rp/bulan) }\end{array}$ & $\begin{array}{r}3,262 \mathrm{E}- \\
07\end{array}$ & 0,007 & 0,966 \\
\hline $\begin{array}{l}\text { Nilai ekonomi masa } \\
\text { depan (skor) }\end{array}$ & $-0,451$ & $-0,097$ & 0,605 \\
\hline $\begin{array}{l}\text { Nilai ekonomi sekarang } \\
\text { (skor) }\end{array}$ & $-0,603$ & $-0,144$ & 0,424 \\
\hline Motivasi intrinsik (skor) & 0,179 & 0,156 & 0,568 \\
\hline $\begin{array}{l}\text { Motivasi ekstrinsik } \\
\text { (skor) }\end{array}$ & $-0,813$ & $-0,734$ & $0,013^{* *}$ \\
\hline $\mathrm{F}$ & & & 1,577 \\
\hline $\mathrm{R}^{2}$ & & & 0,450 \\
\hline Adj. $R^{2}$ & & & 0,165 \\
\hline
\end{tabular}

Keterangan:

*signifikan pada $p<0,1,{ }^{*}$ signifikan pada $p<0,05$,

$\mathrm{B}=$ Tidak terstandardisasi, $\beta=$ Terstandardisasi

\section{PEMBAHASAN}

Self-esteem pekerja anak dipengaruhi secara signifikan oleh lama pendidikan pekerja anak, status pendidikan pekerja anak, dan motivasi ekstrinsik. Pertama, lama pendidikan pekerja anak berpengaruh positif dan signifikan terhadap self-esteem. Hasil ini menunjukkan bahwa pendidikan dapat meningkatkan selfesteem anak. Pertambahan lama anak dalam mengikuti pendidikan formal dapat meningkatkan self-esteem anak menjadi lebih baik. Pekerja anak yang semakin lama menempuh pendidikan akan semakin paham potensi dirinya sehingga anak mampu menghadapi sindiran negatif dari temantemannya di sekolah. Desmita (2008) menjelaskan bahwa kemampuan potensi kognitif remaja yang telah mencapai kematangan mampu melakukan kritik terhadap masyarakat, orang tua, dan bahkan terhadap kekurangan diri mereka. Oleh karena itu, selfesteem pekerja anak tidak menurun seiring 

dengan semakin lamanya anak menempuh pendidikan. Sebagian anak justru merasa lebih unggul dibandingkan teman-teman lainnya dalam pelajaran sejenis keterampilan tangan karena anak telah memiliki pengalaman membuat sepatu.

Kedua, status pendidikan pekerja anak berpengaruh secara negatif dan signifikan terhadap self-esteem. Pekerja anak yang memiliki status pendidikan bersekolah akan menjadikan self-esteem semakin rendah. Pekerja anak terkadang mendapatkan perlakuan yang tidak menyenangkan ketika berada di sekolah. Sebagian pekerja anak mengaku bahwa dirinya pernah dikucilkan dan diejek oleh teman-temannya karena orang tuanya bekerja membuat sepatu. Hal tersebut menjadikan pekerja anak merasa terkadang malu untuk bermain bersama teman-temannya. Padahal penerimaan teman sebaya sangat berpengaruh terhadap kondisi psikologis anak. Desmita (2008) mengatakan bahwa penerimaan teman-teman sebaya akan memberikan perasaan senang terhadap remaja, sehingga self-esteem remaja akan meningkat. Perilaku pekerja anak yang merasa sendiri karena sikap penolakan teman sebayanya tersebut justru semakin menurunkan self-esteem anak. Salmivalli (2001) mengatakan bahwa ketika self-esteem individu rendah maka hal tersebut berkaitan dengan sikap depresi, ketakutan yang mencekam, sikap malu, dan kesendirian. Perlakuan yang tidak menyenangkan di sekolah akan mengganggu kondisi psikologis anak diantaranya anak mengalami depresi dan penurunan self-esteem anak (Chen \& Wei, 2011).

Ketiga, motivasi ekstrinsik berpengaruh negatif dan signifikan terhadap self-esteem. Hasil ini menunjukkan bahwa motivasi ekstrinsik yang semakin tinggi dapat menurunkan self-esteem anak. Pekerja anak memiliki motivasi ekstrinsik yang tinggi menunjukkan bahwa pekerja anak mendapatkan pengaruh sosial yang kuat dari lingkungan sekitarnya. Hal ini terjadi karena masyarakat setempat memiliki pandangan negatif terhadap pendidikan. Anak yang menempuh pendidikan tinggi tidak menjadi jaminan keluarga karena masa depan anak juga akan tetap bekerja seperti orang tuanya. Penilaian tersebut yang akhirnya menjadikan self-esteem rendah yakni pekerja anak memiliki perasaan yang minder, pekerja anak tidak yakin terhadap masa depannya, dan perilaku pekerja anak menjadi antisosial. Calhoun dan Acocella (1990) mengatakan bahwa mengandalkan penilaian hanya dari orang lain dapat menimbulkan kerugian besar terhadap konsep diri. Ada tiga alasan yang mendasarinya. Pertama, individu tidak dapat mengetahui hal yang dipikirkan oleh orang lain. Pendapat orang lain dapat berubah dan tidak akan pernah mencapai penilaian akhir. Kedua, orang lain tidak selalu benar menilai individu. Ketiga, individu tidak dapat menyenangkan semua orang sepanjang waktu.

\section{SIMPULAN DAN SARAN}

Nilai ekonomi anak dilihat dari nilai ekonomi anak masa depan dan nilai ekonomi anak saat ini. Nilai ekonomi anak saat ini berbeda signifikan antara pekerja anak laki-laki dan pekerja anak perempuan. Nilai ekonomi anak masa depan dan sekarang yang lebih tinggi dibandingkan perempuan. Motivasi (intrinsik dan ekstrinsik) dan self-esteem pekerja anak berada pada kategori sedang. Motivasi dan juga self-esteem pekerja anak laki-laki lebih tinggi dibandingkan pekerja anak perempuan. Self-esteem pekerja anak meningkat dengan bertambahnya lama anak untuk mengikuti pendidikan prasekolah formal dan menurun pada anak yang putus sekolah. Self-esteem pekerja anak ini juga menurun dengan berkurangnya motivasi ekstrinsik. Adapun variabel yang memengaruhi selfesteem secara positif yakni lama pendidikan.

Pendapatan yang diperoleh dari bekerja sebagai pekerja anak tidak berkontribusi besar dalam pendapatan keluarga. Oleh karena itu, orang tua lebih baik memfokuskan anak sebagai investasi jangka panjang dengan cara menyekolahkan anak hingga pendidikan yang tinggi. Pendidikan yang tinggi mendorong anak untuk memiliki self-esteem yang semakin baik.

\section{DAFTAR PUSTAKA}

[BPS] Badan Pusat Statistik. (2010). Jumlah persentase penduduk miskin, garis kemiskinan, indeks kedalaman kemiskinan, dan indeks keparahan kemiskinan menurut provinsi. Diambil dari:http://www.bps.go.id/tab_sub/view.php ?tabel=1\&daftar $=1 \&$ id-subye $\bar{k}=$ 23\&notab=4. [diunduh 15 Ags 2011].

Bryant, W. K. (1990). The economic organization of the household. United states of America, US: Cambridge University Press.

Calhoun, J., \& Acocella, J. R. (1990). Psikologi tentang penyesuaian dan hubungan kemanusiaan. Satmoko R.S., penerjemah. 

Semarang, ID: IKIP Semarang Press. Terjemahan dari: Psychology of Adjustment and Human.

Chen, J. K., \& Wei, H. S. (2011). The impact of school violence on self-esteem and depression among Taiwanese junior high school students. Social Indicator Research, 100, 479-498.

Desmita. (2008). Psikologi perkembangan. Bandung, ID: PT Remaja Rosdakarya.

Harril. (2008). Self-esteem inventarisation. Diambil dari: http://www.innerworkspublishing.com. [diunduh 27 Mar. 2011] .

Hurlock, E. B. (1980). Psikologi perkembangan. Edisi ke-5. Jakarta, ID: Erlangga

[ILO] International Labour Office. (2007). Child labour on tobacco plantations in North Sumatera Province. Jakarta, ID: International Labour Office.

Kartino, T. (2005). Nilai anak dan kualitas pengasuhan anak usia sekolah pada keluarga nelayan (skripsi). Institut Pertanian Bogor, Bogor.
Kogitcibasi, C. (2007). Family, self and human development across culture, theory and application, second edition. US: Lawrence Erlbaum Associates, Inc.

Papalia, D. E., Olds S. W., \& Feldman R. D. 2008. Human development (perkembangan manusia). Marswendy B, penerjemah; Widyaningrum $\mathrm{R}$, (Eds.). Ed ke- 10. Jakarta, ID: Salemba Humanika.

Salmivalli, C. (2001). Feeling good about oneself, being bad to others? remarks on self-esteem, hostility, and aggressive behavior. Journal Aggress and Violet Behavior, 6, 375-393.

Santrock, J. W. (2003). Perkembangan Remaja. Adelar SB, Sherly Saragih, penerjemah. Jakarta, ID: Erlangga. Terjemahan dari Adolescence Development.

Usman, H., \& Nachrowi, N. D. (2004). Pekerja anak di Indonesia: kondisi, determinasi, dan eksploitasi. Jakarta, ID: PT Gramedia Widiasarana Indonesia. 